\title{
Going, going, gone: a feminist Bourdieusian analysis of young women's trajectories in, through and out of physics, age 10-19
}

\author{
Louise Archer, Emily MacLeod and Julie Moote
}

UCL Institute of Education, UK.

\begin{abstract}
This chapter draws on longitudinal interview data collected from seven young woman in England who were tracked from age 10-19 and who had all expressed an aspiration at age 16 to study Advanced level (A level) physics. Applying a feminist Bourdieusian conceptual lens, we explore their trajectories in, through and out of physics: from Danielle, who is denied entry to A level physics; to Victoria and Thalia, who are debarred from the course before completion; to Davina, Kate and Mienie, who complete the A level but who choose not to pursue the subject further; and finally Hannah, who goes on to study physics at university. Attention is drawn to the pedagogic work conducted by the field of physics, notably the cultivation of habitus and hexis through the bodies, minds and identities of the young women, and its stringent gate-keeping practices, which ensure the reproduction of the elite status of the field and the simultaneous disadvantaging of women.
\end{abstract}

\section{The exclusion of women and femininity from physics}

The 'gender problem' in physics is a long-standing and widely recognised issue. Women remain under-represented in post-compulsory physics (e.g. Smith 2010a,b; 2011), despite decades of interventions aimed at improving the gender profile of physics (Darke, Clewell, \& Sevo 2002). These differences are not the result of inequalities in female attainment in the subject (Haworth, Dale \& Plomin 2008; Smith 2011; Tan et al., 2013; Tytler et al 2008). Rather, attention has been drawn to the masculine culture of science (Harding 1998; Haraway 1988), and the multiple ways in which this disadvantages and excludes women (Blickenstaff 2005), through explicitly gendered curricula and representations of the subject (e.g. Baker \& Leary 1995;) which girls struggle to find relate to (Calabrese Barton \& Brickhouse 2006; Calabrese Barton, Tan \& Rivet 2008; Haussler \& Hoffmann, 2002), to the gendered biases of teachers (Carlone 2004), and these unconscious 
understandings people have developed in which physics is seen as being 'for boys', such that girls receive less encouragement from others to pursue the subject (Mujtaba \& Reiss, 2013). Indeed, even those women who pursue the subject at degree level find it hard to reconcile their femininity with a legitimate physics identity (Danielsson, 2012; Gonsalves, 2014).

\section{A feminist Bourdieusian conceptual lens}

Despite Bourdieu's relative lack of interest in gender in this work (cf. Bourdieu 2001), feminists have still found his theoretical tools useful and productive, particularly for reconceptualising identity - as simultaneously part of (produced by and incorporating) the social world. As Adkins explains, 'the notion of the subject as not simply engaged with the world, but in the world, is one which has great appeal to feminists' (Adkins, 2004: 10, emphasis in original). Bourdieu's theory breaks down the Cartesian dualism and provides a framework in which gender can be understood as not just a product of the mind/ consciousness. That is, his work provides a conceptual framework for understanding gender whereby 'mind and body, thought and action, are indissolvable' (Adkins 2004, p.11).

Drawing on Moi (1991, 1999), Adkins (2004) argues that gender is best conceptualised as part of the general social field, being 'extraordinarily relational, with a chameleon-like flexibility, shifting in importance, value and effects from context to context or from field to field'. In other words, gender is both 'dispersed across the social field and deeply structuring of the social field' (Adkins 2004, p.6).

For feminists, Bourdieu's emphasis on embodiment is also highly congruent with feminist approaches to identity, as epitomised by his conceptualisation of the habitus (the internal framework of socialised dispositions which is both structured by and structuring of experience) as being both an embodiment of the social world (hexis) and a socialised body that shapes the social world.

While feminists have generally found little use for Masculine Domination (2001) per se, Bourdieu's sole text focusing on gender, there is a treasure trove of feminist extensions and adaptions of his main ideas. For instance, McNay (1999) extends Bourdieu to understand gender as 'a lived social relation which will always involve conflict, negotiation and tension' (Adkins 2004: 11), in which experience is always relational but not foundational. Lawler (2004) has also provided a feminist Bourdieusian analysis of how gendered and classed identities are conferred on subjects via cultural authorization by the media. 


\section{The Aspires/ Aspires2 study}

For our analysis, we draw on data that were collected as part of the Aspires/ Aspires2 project - a ten year, mixed methods study of children's science and career aspirations from age 10-19 that was funded by the UK Economic and Social Research Council. Our wider dataset comprises large-scale national surveys of a cohort of students as they progress through primary and secondary schooling, combined with in-depth longitudinal interviews with a subset of young people and their parents (e.g. see Archer et al. 2017). However, for this chapter, we focus on a subset of interviews that were conducted with seven young women: Danielle, Davina, Hannah, Kate, Mienie, Thalia and Victoria (see Table 1). These young women were selected from the wider dataset on the basis that by 16 (Year 11,. in the English school system), they had all expressed an aspiration to study Advanced level (A leveli) Physics. Interviews were conducted at five time-points; Year 6 (10/11), Year 8 (11/12), Year 9(12/13), Year 11 (14/15), and Year 13 (age 17/18).

Table 1: Demographic details of the seven young women

\begin{tabular}{|l|l|l|l|l|l|l|}
\hline Name & $\begin{array}{l}\text { Science } \\
\text { GCSEs }\end{array}$ & $\begin{array}{l}\text { Science A } \\
\text { levels }\end{array}$ & $\begin{array}{l}\text { Post-18 } \\
\text { destination }\end{array}$ & $\begin{array}{l}\text { Social } \\
\text { class }\end{array}$ & Ethnicity & $\begin{array}{l}\text { Gender } \\
\text { identity } \\
\text { at age 18 }\end{array}$ \\
\hline Danielle & $\begin{array}{l}\text { Double } \\
\text { science }\end{array}$ & - & $\begin{array}{l}\text { Sociology } \\
\text { degree }\end{array}$ & $\begin{array}{l}\text { Working- } \\
\text { class }\end{array}$ & $\begin{array}{l}\text { White } \\
\text { British }\end{array}$ & Female \\
\hline Davina & $\begin{array}{l}\text { Triple } \\
\text { Science } \\
\text { physics, } \\
\text { chemistry }\end{array}$ & $\begin{array}{l}\text { Maths, } \\
\text { (with offer } \\
\text { for } \\
\text { Chemistry } \\
\text { degree next }\end{array}$ & $\begin{array}{l}\text { Upper } \\
\text { middle- } \\
\text { class } \\
\text { year) }\end{array}$ & $\begin{array}{l}\text { White } \\
\text { British/ } \\
\text { European }\end{array}$ & Female \\
& $\begin{array}{l}\text { Triple } \\
\text { Science }\end{array}$ & $\begin{array}{l}\text { Chemisty, } \\
\text { maths, } \\
\text { further } \\
\text { maths, } \\
\text { physics }\end{array}$ & $\begin{array}{l}\text { Physics } \\
\text { degree }\end{array}$ & $\begin{array}{l}\text { Upper } \\
\text { middle- } \\
\text { class }\end{array}$ & $\begin{array}{l}\text { White } \\
\text { British / } \\
\text { North } \\
\text { American }\end{array}$ & Female \\
\hline
\end{tabular}




\begin{tabular}{|c|c|c|c|c|c|c|}
\hline Kate & $\begin{array}{l}\text { Triple } \\
\text { Science }\end{array}$ & $\begin{array}{l}\text { Biology, } \\
\text { chemistry, } \\
\text { physics, } \\
\text { maths }\end{array}$ & $\begin{array}{l}\text { Natural } \\
\text { sciences } \\
\text { degree }\end{array}$ & $\begin{array}{l}\text { Upper- } \\
\text { middle- } \\
\text { class }\end{array}$ & $\begin{array}{l}\text { White } \\
\text { British }\end{array}$ & Female \\
\hline Mienie & $\begin{array}{l}\text { Triple } \\
\text { science }\end{array}$ & $\begin{array}{l}\text { Chemistry, } \\
\text { Maths, } \\
\text { Physics }\end{array}$ & $\begin{array}{l}\text { Gap year } \\
\text { (before } \\
\text { taking up } \\
\text { offer to do } \\
\text { Chemistry } \\
\text { degree) }\end{array}$ & $\begin{array}{l}\text { Middle- } \\
\text { class }\end{array}$ & $\begin{array}{l}\text { South } \\
\text { Asian }\end{array}$ & Female \\
\hline Thalia & $\begin{array}{l}\text { Triple } \\
\text { science }\end{array}$ & $\begin{array}{l}\text { - (started } \\
\text { but did not } \\
\text { finish } \\
\text { physics A } \\
\text { level) }\end{array}$ & $\begin{array}{l}\text { Japanese } \\
\text { studies } \\
\text { degree }\end{array}$ & $\begin{array}{l}\text { Middle- } \\
\text { class }\end{array}$ & $\begin{array}{l}\text { White } \\
\text { British }\end{array}$ & Other \\
\hline Victoria & $\begin{array}{l}\text { Triple } \\
\text { science }\end{array}$ & $\begin{array}{l}\text { Maths, DT } \\
\text { (started } \\
\text { but did not } \\
\text { finish } \\
\text { physics A } \\
\text { level) }\end{array}$ & $\begin{array}{l}\text { HE } \\
\text { foundation } \\
\text { engineering } \\
\text { course } \\
\text { (with view } \\
\text { to do } \\
\text { electrical } \\
\text { engineering } \\
\text { degree } \\
\text { following } \\
\text { year) }\end{array}$ & $\begin{array}{l}\text { Middle- } \\
\text { class }\end{array}$ & $\begin{array}{l}\text { White } \\
\text { British }\end{array}$ & Female \\
\hline
\end{tabular}

As can be seen from Table 1, six of the girls went on to study advanced level physics (Davina, Hannah, Kate, Mienie, Thalia and Victoria) but the seventh, Danielle, was dissuaded by her school from taking the subject.

Four of the young women successfully completed physics A level (Davina, Hannah, Kate and Mienie) but two were deselected from the course by their school part way through their studies (Thalia and Victoria). 
Only one young woman (Hannah) went on to study for a physics degree, although five of the seven young women pursued other science/ STEM-related routes post-18.

Using our analytic lens, we now explore the young women's accounts in more detail to try to understand the processes at work which facilitate, or prevent, their physics trajectories.

\section{Impossible female physicists - girls denied entry and/or debarred from A level physics}

There were three girls (Danielle, Thalia and Victoria) who at age 15/16 had wanted to study A level physics but who ended up not achieving this goal. All three girls were interested in the subject:

I love Physics [...] I like it because Physics is kind of like Maths and English and it's one ... like it's ... if you were sitting in ... let's say [...] if you were sitting a Physics exam you can read the question and work ... do the equations and work it out, even if you knew nothing about what it was all about [...] That's what I like about Physics. It's kind of like common sense. (Danielle, Y11)

I was doing Psychology, but then I decided ... I was talking to my Physics teacher about Physics, because I really like Physics and he said he did think I'd do fine, because I didn't think I'd do well in Physics, but he kind of was like no, you'll do all right. You'll be fine, so then I changed Psychology to Physics. (Thalia, Y11)

I do enjoy Physics [...] I just like knowing how things work, what's going on out there in space and everything. Just I like knowing what's - why things do what they do. (Victoria, Y11)

In other words, none of these girls seemed to suffer from a lack of interest, aspiration or inspiration - as is so often assumed by initiatives aimed at encouraging girls into physics. Rather, in each case, as we now discuss, we interpreted their inability to continue as due to stringent gatekeeping - and practices of debarring - enacted by the education system.

Prior to taking her GCSE examinations (the national examinations taken at age 16 in England), Danielle had told her school that she wanted to study A level physics. In her Y11 interview she told us that the school had explained that acceptance onto the A level course would be dependent on achieving a $\mathrm{B}$ grade in science in her upcoming GCSE examinations: 
"I was going to take Physics but I've got to wait and get my results from my exams back because if I don't get a B, I can't do physics" (Y11)

She chose psychology as a back-up subject, although maintained a preference for physics ("if I can get it"). In the end, after not attaining a B grade in Physics GCSE, Danielle studied Sociology A level (along with English, Media and Health \& Social Care) because she did not attain the B grade in maths that was required for entry to Psychology A level. After her results, Danielle had asked her school again to be considered for A level Physics and although the teacher initially consented to possibly give her a 'trial', Danielle was informally persuaded that she would probably find the course too difficult and, in end, did not take up the trial offer.

"I asked my teacher if I could do physics, even though I had a C and she said 'yeah' but then I got put off because apparently it's really hard" (Y13)

Danielle reflected that "at the time I was upset" but consoled herself that it was probably the 'right' decision "cos I know so many people that are like failing science [...] like really failing" (Y13 interview).

Unlike Danielle, while Thalia and Victoria were allowed entry to physics A level, both were expelled from the course by their respective schools at the end of their first year of study and were not allowed to progress with the subject. In both of their cases, the reason for this debarring was on the basis of insufficiently high attainment to date on the course. As Thalia put it, "I didn't do very well in physics" and got a low mark on her end of year mock examination. Victoria similarly 'failed' the first year mock examination and explained that her teachers had advised her that she drop out altogether and not return to the college at the start of the next academic year:

'I was on the cusp of being told like 'sorry, no you can't come back' and they [teachers] strongly advised not coming back. But I came back and now I'm [predicted as] going to get an A in DT [Design Technology], I'm going to get a B in Politics and - not so great but - I'm going to get a D in Maths"

Based on the grades she obtained at the end of Year 13, Victoria entered a one year engineering foundation course, from which she planned to go on to an electrical engineering degree. She explained that she made her choice of engineering course and degree pragmatically, via a 'process of elimination', according to her grades and the course entry requirements).

Victoria thus agentically negotiates the schools' 'advice' that she not continue, to carve out a route towards an engineering degree, in order to achieve her long-held aspiration. Importantly, Victoria has a range of cultural, social and science-related capital to draw on that helps her navigate this trajectory - and which helps her to mitigate the pedagogic work undertaken by the school, encouraging her to 'leave'. However, we also note the imprint of the field on her habitus in that she 
blames herself for her 'failure' to continue and does not question the legitimacy of the decision. For instance, she does not question the attainment bar as an arbiter of who is allowed to continue with the subject, nor does she question the arbitrary 'jump' in 'difficulty' from GCSE to A level. Rather, she locates the issue as her inability to 'click' with the subject:

"I didn't click with any of the Physics. I feel like that was always a bit hopeless, but I got a

B at GCSE, but that compared to A level it's just not even comparable"

Applying our conceptual lens, we interpret this as the effect of long-term pedagogic action, which reproduces physics as an elite subject, whereby the practices that are key to maintaining this eliteness (e.g. performances of high attainment as both a pre-requisite for acceptance on to the A level and for retention while studying the course; grade severity and arbitrarily 'difficult' content at A level; the requirement for physics on higher status engineering degrees) are not questioned but are accepted as doxa. As a result, 'failure' is ascribed to the individual student. Indeed, both Thalia and Victoria accepted the legitimacy of the decision to debar them from the course. From a Bourdieusian analysis, this might be read as an example of practical faith - whereby practices of debarring are designed to obtain 'native compliance' (Bourdieu 1990b, p.68). We suggest that the example practices noted in our data set are not uncommon, as national government data indicates that physics A level typically demands higher level entry qualifications (typically A/A*) compared to other subjects (OfQual 2017). Moreover, several analyses suggest that physics A level is marked more harshly than other subjects, making it more difficult to achieve a high grade and, in turn, encouraging schools to enact more stringent gate-keeping practices in the subject (Thomson, 2015; Tracy, 2016a,b).

Such practices are key to the reproduction of the doxa that physics is 'difficult' and only for the 'clever'. These practices operate as a form of pedagogic work, not only controlling who is allowed to enter and remain on A level physics courses, but also - as we discuss next - cultivating the habitus, such that many students come to self-exclude from continuing with physics.

\section{Self-exclusion and the cultivated habitus - young women who leave physics after A level}

Three of the seven young women - Davina, Kate and Mienie - completed A level physics but did not choose to continue the subject post-18. As we have written previously (Archer et al., 2017), compared to girls in the wider data set, these young women were all highly 'exceptional'. Not only were they unusual given the very low proportion of girls who study physics, but they were also distinctive on account of possessing high levels of (cultural, social and specifically science capital), 
achieving very highly in academic terms, and on account of their relative comfort with 'being different' from the majority of girls with regard to their gender identity. In particular, they did not conform to 'girly' popular femininity. In short, they were, as Davina put it in her Year 11 interview, 'not like your average person':

"Maybe not a lot of people are good at Science and maybe that's kind of the beauty of being someone that is good at Science, I guess. The fact that maybe you're not like your average person" (Davina, quoted in Archer et al., 2017, p.100).

However, over the course of studying A level physics, these three young women came to view that degree level physics was not 'for me'. Unlike Danielle, Thalia and Victoria, they were not debarred from continuing, indeed, they achieved grades (e.g. Davina, A, Kate, A*), which would have enabled them to apply to study the subject at degree level. Rather, we now discuss, they selfexcluded, which we interpret as due to pedagogic work conducted by the subfield of school physics, enacted through the notion of the 'effortlessly clever physicist'.

As we have noted among younger female students (Archer et al., 2013) and indeed among secondary students more generally (Archer et al., 2017), physics has a long-standing association with notions of 'cleverness' and is widely identified as being the 'hardest' of the sciences. The girls who continued with A level physics were no exception and notions of cleverness (as 'measured' through the metric of attainment) were frequently brought up within the girls' reflections regarding whether they felt they could continue further with physics, or not, post-18. For instance, Kate described how despite having 'always liked' physics, she had always questioned whether it might be 'for me' due to the need to continually produce high levels of attainment to remain viable as a physics student:

"I think I've like always liked physics, but always thought it was quite hard, so maybe not for me, but then I was like 'oh well I'm doing okay at school. I might as well keep it up as long as I can"” (Kate, Y13)

Kate's insecurity is particularly striking as she actually recorded the highest GCSE and A level attainment out of all the students we followed in the study, achieving $10 \mathrm{~A}^{*} \mathrm{~s}$ at GCSE and $3 \mathrm{~A}^{*} \mathrm{~s}$ and an A grade at A level. We interpret her concern - that physics is "quite hard, so maybe not for me" as an exemplifying the effect that the subject (and its concerted pedagogic work) has had on her habitus, notably inculcation of the expectation that only the 'cleverest' and highest attaining students are legitimate participants in the subject. Hence, despite her clear aptitude, interest and credentials, Kate excluded herself from the possibility of studying a physics degree, worrying that it would be 'too hard': 
I wouldn't do like a straight physics degree, because it would be too hard. Like I think I'm just a bit put off by thinking that it would be really hard. [...] So yeah, I think what put me off doing straight physics was that I think it's too hard and what put me off straight Biology is I'd quite like to do some physics as well. (Kate, Y13).

Davina's identification with physics - and the extent to which she considered herself a viable physicist - shifted over the years due in no small part, we would argue, to dominant associations of the subject with a particular notion of cleverness. Davina was a student with similarly high attainment (for instance, in her GCSE examinations she gained $8 \mathrm{~A}^{*} \mathrm{~s}$, which included maths and sciences, 2 As and a B grade) and was studying maths, chemistry and physics at A level (all of which she achieved at grade A). When we interviewed her between the ages of 12 and 16, she had identified strongly with physics. As she reflected at age 18, "like definitely I was more like a physics... person". However, over the course of studying A level physics, despite her continued interest in the subject, Davina became less sure that degree-level physics was 'for her' and eventually applied to study for a chemistry degree instead. She described this process of negotiation at some length in her interview, which as the following extract shows, centred around the question of 'cleverness':

"I mean certainly if someone said 'do you think you're clever enough to do physics at university?', I would say definitely not, most definitely not ... like no way I could do physics at university [...] I mean I guess I'm probably smart enough to like get the A level, and then I don't think that necessarily means that I'm actually like that good at physics, if you know what I mean?" (Davina, Y13, emphasis added)

As we discuss in Archer et al,, (under review), most of the young women (whether they continued with the subject or not) struggled to recognise themselves as being 'good at physics', irrespective of their actual attainment (Mujtaba \& Reiss, 2013). Moreover, we interpreted the young women's accounts as highlighting a specific configuration of physics cleverness, one that must be 'natural' or 'effortlessly' produced in order to be legitimate. That is, one is either "clever enough", or not, to take the subject further - rather than, for instance, being able to continue on the basis of hard work and application.

Indeed, Davina described how she usually understood concepts and content more quickly and easily in the other sciences ("for most things in science I do tend to understand them like first time"), but that this is not the case with A level physics ("in physics, I don't"). Mienie expressed a similar sentiment: 
"I mean physics is really hard but I enjoy physics even though it is quite hard. I have to work quite hard for it ...yeah, I don't know why but it's, I don't know, because some things come naturally to you and physics, it did, but then..."

That is, the young women were concerned by their need to 'work quite hard' to understand A level physics and interpreted this as evidence that they were not authentic or viable degree level physicists. This notion was further cultivated by their perception that some peers (whether 'real' classmates, in Davina's case, or 'imagined' by Kate) did not have to exert a similar effort:

"Part of the reason why I'm maybe putting myself down slightly is probably because I'm comparing myself to people who are just kind of like ... you know kind of again pretty much breezing through and getting like you know $80 \%$ or whatever. And then I'm there like trying really hard and getting less than that." (Davina, Y13).

Indeed, all three girls felt that they had to work much harder in physics than the other sciences - but rather than interpreting this as (for instance) the potential result of a more challenging curriculum, harder marking or more variable teaching, they located the 'fault' within their own essentialised capabilities (being 'not clever enough' to study physics at university). Although Mienie did hint at the issue of teacher quality at other points in her interview, as the following point exemplifies, this was underscored by her description of how the teacher enacted pedagogic work by reproducing the notion of physics as not just 'hard' but is even potentially 'unknowable' by the students:

Um, so for Physics I have two different teachers and the one particular teacher she, her teaching style is very not good. [Int: Oh] I'm just going to say not good. ...Um, so yeah she, I mean she admits it herself sometimes that, sometimes she'll be explaining something and she'll just say 'oh if I was you, I wouldn't understand it myself' and I would think, yeah. (laughs) (Mienie, Y13)

We interpret these young women's accounts as hinting at the cultivated physics habitus, in which a legitimate physics identity is aligned with 'effortless achievement' (Bourdieu \& Passeron, 1977). The notion of 'effortless' achievement has been identified by feminists as being a gendered construction that is aligned with masculinity, whereas attainment via 'effort' is associated with femininity (e.g. see Francis and Skelton, 2005). Indeed, Carlone's (2004) study shows how powerfully these associations are within the context of advanced physics courses, such that teachers attributed boys' attainment to 'raw talent', whereas they explained away girls' (higher) attainment as achieved via 'plodding diligence' (and hence as not being produced from 'natural' aptitude for the subject). 
We read the young women's accounts as showing traces of the symbolic violence that is inculcated within the habitus through their physics socialisation. As Bourdieu and Wacquant explain, symbolic violence is "the violence which is exercised upon a social agent with his or her complicity" (2002, p.167, italics in original). That is, the girls attribute the 'blame' and failure to themselves and selfexclude themselves from the possibility of taking the subject further. Indeed, despite attaining a top grade in A level physics, Kate said self-deprecatingly in the interview, "I just don't really understand it that well". When probed as to whether her classmates understood the content better, she could not identify anyone, but conceded that her reference point (for the legitimate 'naturally' clever physics student) was "maybe imagined" (Kate, Y13). We interpret this notion (of the imagined legitimate, effortlessly clever physicist) as hinting at the pedagogic action underlying such practices - namely, the myriad of everyday acts and practices that support the reproduction of the elite status of physics by restricting the entry and retention of all but a privileged few. That is, we suggest that the students' accounts hint at pedagogic work which is undertaken within the teaching and learning of A level physics which inculcates students to accept that physics is not just 'hard' but is 'too hard for all but the 'natural', effortlessly clever (male) physicist - and that the propagation of this fantasy is an integral part of the reproduction of the elite status of the subject.

In other words, we argue that the notion of the 'effortlessly clever physicist', which is cultivated through a range of practices enacted within school physics and the wider media (as epitomised by the character of Sheldon in popular US TV comedy, The Big Bang Theory), seemed to play a key role deterring even highly able, qualified and interested young women from seeing post-18 physics as appropriate and attainable. Rather than being debarred, we suggest that the doxa of the 'effortlessly clever physicist' works silently and perniciously to make many students question their own legitimacy as someone who is 'actually good' at the subject and hence viable as a degree candidate, irrespective of their interest, enjoyment and attainment in the subject. Thus symbolic domination is achieved through the self-regulation of the cultured habitus. As Jenkins writes, pedagogic work aims to produce within the habitus 'dispositions which generate 'correct' responses to the symbolic stimuli emanating from agencies endowed with pedagogic authority" (2006, p.107) - such as the notion of who is 'clever enough' to continue with physics. This process is particular effective and powerful:

"The legitimate culture becomes experiences as an axiom, a fait accompli: Children all too soon stop asking 'Why?' Exclusion works most powerfully as self-exclusion” (Jenkins, 2006, p.107). 
Writing in the context of the production of working-class 'taste', Bourdieu argues that the workingclass make a virtue out of a necessity ('that is to refuse what is categorically denied and to will the inevitable' - 1990b), 'inducing 'choices' which correspond to the condition of which it is a product' (Bourdieu, 1984, p.175). We suggest that this account seems to have some purchase for explaining the self-exclusion of Davina, Kate and Mienie from post-18 physics, but how does it account for Hannah, who - as discussed next - went on the study for a degree in physics?

\section{Last woman (physicist) standing - Hannah}

Hannah was the only girl who, after completing A level physics, applied for a physics degree. She recorded high levels of attainment $7 \mathrm{~A}^{*} \mathrm{~s}$ (inc. maths \& science), 3As and a B at GCSE, and $4 \mathrm{~A}^{*} \mathrm{~s}$ at A level (in chemistry, physics, mathematics and further mathematics), although these were not notably higher than Kate, Davina and Mienie (who took physics A level but who did not continue further with the subject). However, Hannah did stand out from her peers in that she did not describe physics as particularly 'hard':

"Well parts of it [physics] are difficult but if you compare that to English I'd say physics was easy. [Interviewer: Right, yeah] Not easy but like easier. It's quite nice, cos if you just understand like the basics, you can pretty much figure out everything from there" (Y13)

As we discuss in Archer et al., (under review), Hannah was also the only girl to assert the view that she might be 'good at physics', although notably she still did not align herself with the notion of the effortlessly clever physicist, claiming that she does not "breeze through" but rather has to "work to understand things":

"Well I'd like to think at least that I am good at physics. But not like breeze through it, you have to still like work to understand things. So probably like in the middle of that. There'll be people who like completely breeze through it - I'm not one of them" (Y13)

Her views thus echo those of Davina, Kate and Mienie - who described having to 'work' at the subject - although unlike Hannah, the others interpreted this requirement of effort as signalling that they should not continue with the subject. We interpret Hannah as negotiating a tricky identity tightrope in which she produces a self-identification as being 'good at physics' (which is dominantly aligned with masculinity) but positions this as being achieved via feminised diligence (having to "work to understanding things"). We suggest that this combination enables her to maintain and intelligible 
femininity and identify as a viable, although not necessarily a dominantly authentic/ legitimate, physicist.

So how and why does Hannah end up pursuing a physics degree when so many other (equally well qualified and interested) young women do not? On one level, a Bourdieusian lens provides a helpful steer by alerting us to the importance of capital for enabling Hannah's physics trajectory. While the other young women who took the A level also enjoyed substantial economic, cultural, social and science-related capital, Hannah undoubtedly possessed the most specifically physics-related capital. For instance, Hannah engaged in a high volume and wide range of science (and physics)-related informal science learning activities over the years, including regularly going on the 'IFLS' website and reading about new developments in physics via a range of physics media:

Physics came first cos I think ... I think I read a book ... I can't remember, it might have been Higgs [about the Higgs-Boson particle], and like I got a subscription to New Scientist for my birthday and I just started reading them. And I was like 'Oh that's actually pretty cool' (Hannah, Y13)

In particular though, Hannah had the most substantial physics-related social capital out of any of the students. She had several family members who were physicists and ended up going to the same university to study physics as her older brother. Such family pathways can foster not only an awareness and desire for particular options but can also provide pragmatic support and mitigation of risk, in that these trajectories constitute 'safe', known routes. For instance, in her Year 11 interview Hannah described the 'reassurance' that she had got from having an older brother who had done a postgraduate physics degree, and whose girl-friend (at the time, the couple later married) was a nuclear physicist and constituted an important source of information and support. In her Year 13 interview, Hannah also described the rich social capital that she derived from knowing the couples' many friends (who Hannah had socialised with) who were also physicists:

"So I talked to her [brother's girlfriend, who is a physicist] quite a lot, cos she also wanted to do Medicine. [She talked] about like what you need to do to either ... well for Physics and for Medicine what you need to do like. And like what the jobs consist of [...] I was quite impressed with my brother's girlfriend cos she did quite like ... well I don't know she just seemed quite cool, cos her job was cool [...] I wouldn't mind doing that.” (Y11).

"Yeah, he [brother] really likes it. And then I started talking to him about it. ... He did a $\mathrm{PhD}$ thing at Manchester, and he said that was amazing, which is one of the reasons I looked at it ... cos I guess it's a bit reassuring if you know somebody's done it and they still liked it afterwards" (Y13). 
Outside of her family, Hannah also felt that it had been important for her to have a best friend who shared her interests:

"She [friend] has the New Scientist and we discuss that as well. [...] So it's definitely helped ... because if you don't have someone sharing your interests it's really hard to like talk about them, which is kind of hard." (Y13).

We suggest that Hannah's impressive physics capital is one of the key factors in understanding her exceptional trajectory into post-18 physics. However, it is not clear why capital alone would necessarily result in Hannah transgressing gendered norms. It is here that the explanatory power of our Bourdieusian conceptual framework struggles and has to work harder. Most of Bourdieu's work was concerned with explaining social reproduction (predominantly in relation to social class) - it is less obvious to what extent it can explain female physics students, as an example of those who 'go against the grain' of social reproduction. The closest example we can find in Bourdieu's work is the example of working class 'survivors' (those who, like Bourdieu himself, attain social mobility through the education system), discussed by Bourdieu and Passeron (1977). This notion is usefully and productively extended by Reay, Crozier \& Clayton (2009) in their study of working-class students who attend an elite university. Using a Bourdieusian lens, Reay et al. empirically unpick how, within the unfamiliar setting of elite Higher Education, the working class habitus can produce a range of 'creative adaptions and multifaceted responses' (Reay et al., 2009: 1103). These adaptions are enabled through a constant 'fashioning and refashioning of the self' through reflexive interactions with the field (Reay et al. 2009, p.1111).

Bourdieu suggested that a habitus which encounters an unfamiliar field (such as the working class student in an elite Higher Education setting) can result in 'a habitus divided against itself' (Bourdieu 1999d). However, arguably for Hannah, the field of physics is not as 'unfamiliar' as elite Higher Education is for working-class students. Indeed, Hannah had been studying the subject for seven years by the time of her last interview. Moreover, as we argued above, the field has been cultivating these students' habitus over time, such as to produce a notable degree of alignment and practical faith. Rather, we propose that we might better understand the A level physics girls as displaying examples of a dissonant habitus that results from intersectional encounters, in which Hannah, as an upper middle-class white young person, is both a member of the dominant ethnic and social class (and hence 'entitled' to continue with an elite subject, such as physics) and occupies a position of subordination by dint of her gender. That is, for Hannah there is no 'sudden shock' of immersion into an alien field (as was experienced by the students in Reay et al.'s study). Indeed, 
some aspects of the field (e.g. the elite class alignment of physics) may be culturally familiar for Hannah. Moreover, we suggest that Hannah's prolonged experience of, and immersion in, physics (both in and out of school) has cultivated a degree of alignment between her habitus and the field. However, Hannah's habitus does have to work hard to resolve tension and dissonance between her femininity and the field of physics (as a field that is dominantly coded as masculine).

In earlier work we noted that, among younger (e.g. age 10-14 year old) science-keen girls, 'bluestocking' performances of femininity were much more common than 'girly' performances of femininity (Archer et al., 2012). This pattern exacerbated over time, such that by A level, none of the six girls studying physics self-identified as 'girly'. Rather, the young women's accounts conveyed a gradual alignment over the years, in which performances of femininity were increasingly regulated and downplayed, as exemplified by Hannah and Davina:

"I'm not ... not particularly feminine ... well I do ballet and everything, so that's quite feminine I guess. But not particularly like ...[...] Um ... well [...] I'm just more comfortable in jeans [...] I've cut my hair really short ... [...] Like really really short" (Hannah, Y11).

“I wouldn't say I'm a particularly feminine person at all. I mean you know like I swear quite a lot (laughs) [...] I swear like a sailor, it's ridiculous. You know I don't ... first of all I don't really dress particularly feminine, like I tend to wear jeans and like band t-shirts and hoodies and stuff, and I wear boys' like skater shoes. So I mean yeah I'm not ... I don't have a particularly feminine voice either ... and I think well so what? - like there's nothing wrong with that, it's just like that's just what I am.” (Davina, Y11).

Hannah and Davina talked about feeling different from many of their female peers, a sentiment that is mirrored in the working-class students in Reay et al.'s study, who also recounted long-standing feelings of difference from their working-class families and peers (in this case, on account of their academic dispositions). For instance, while in her earlier interviews, Hannah described feeling different to other girls, over time she developed this into a point of value describing herself by the age of 16 as being "proud to be different" to other girls (see Archer et al., 2017).

While there may be some echo here with Bourdieu's discussion of how the working-class often make a 'virtue out of a necessity' (1984, p.175), we suggest that this case differs due to the differential 
power relations in play. That is, while it becomes necessary for Hannah to eschew popular femininity in order to be intelligible as a physicist (see Archer et al., 2017) - because 'girly' femininity is dominantly configured as the antithesis of 'serious', masculine, rational physics (Francis et al. 2017) - unlike the working-classes discussed by Bourdieu, who are finding ways to 'make do' with their subordinated social position, Hannah is pursuing an elite trajectory. In this respect, while Hannah may need to negotiate the 'loss' (or suppression) of some valued aspects of femininity, as a high status route aligned with masculinity, physics also offers her a chance to 'get on', rather than 'make do'.

We thus interpret Hannah's gender performances as strategic and required adaptions to the field, aimed at resolving her gender dissonance to enable a successful trajectory, but also cultivated as part of her unconscious socialisation by/ into the field. Indeed, Bourdieu recognised that habitus can be changed by field, being 'restructured, transformed in its make-up by the pressure of the objective structures' (Bourdieu, 2005: 47), such that habitus constitutes an 'open system of dispositions' that are 'endlessly transformable' (Bourdieu 1990b, p.116). In this respect, we suggest that the young women who continue with physics may exemplify a process which Puwar (2004, p.128) describes as one whereby they come to 'partially mirror and clone the self-image of the hegemonic norm'. Moreover, we suggest that Hannah's physics aspirations are arguably in line with Bourdieu's logic of capital accumulation (which he considers to be a driver of the habitus), in that she is investing in a trajectory that offers status and capital.

Hannah's lived experience of femininity may also constitute a resource and form of capital that actively supports her physics trajectory. For instance, Reay et al. (2009) discuss how working-class students' experiences of living subordination can lead to resilience, self-reliance and determination, which support and facilitate the students to be successful in their elite Higher Education trajectories. Likewise, it is possible that Hannah's gendered experiences (both generally and specifically in relation to being a woman in the male-dominated field of physics) have provided her with 'grit', resilience and self-sufficiency that will support her onward progression. Reay et al. suggest that the development of such qualities may be key for enabling the successful trajectories and experiences of 'non-traditional' students within elite fields:

“... these students are Bourdieu and Passeron's (1977) working-class exceptions that prove the rule. Their combination of highly developed academic dispositions and reflexive habituses generate opportunities and academic success". (Reay et al., 2009, p,1115). 
These embodied resources may be developed through reflexivity - which Bourdieu suggests is key for the transformative habitus (or as Adkins 2004, p.10 explains it, 'Bourdieu will always break with his main theoretical principles and will see the possibilities for social change when a conscious or thinking mastery of the principles of the habitus can be gained'). Arguably, Hannah - and indeed the other girls who completed Physics A level - displayed reflexive habituses. For instance, Hannah recounted how she was highly aware of being in a gender minority (as a girl studying physics and further maths in a co-educational school) and had thought (and internally debated) the issue extensively when choosing her courses.

“... because I knew I was going to be the only girl, I was getting really worried because then I was like ... if I'm the worst in the class it's just going to be like extra pressure because you don't want to ... I guess being a girl can put extra pressure on you, cos you don't want to be like 'oh you're bad because you're a girl'. And you don't want to be the worst and then people would be like 'Oh"' (Hannah, Y13).

As her extract exemplifies, this awareness of her gender difference and hypervisibility was experienced as an 'extra pressure', such that any individual academic 'failings' would be interpreted as due to her gender ('oh you're bad because you're a girl'), thus justifying and reinforcing her gender 'illegitimacy' within the field of physics. Moreover, while the idealised notion of the 'effortlessly clever physicist' may not be restricted solely to female students (as discussed in our other chapter in this volume, discussing Victor's physics trajectory), it was an even more difficult and higher stakes challenge for young women to negotiate.

Reay et al. (2009) describe how working class students' habitus was fashioned and refashioned through their experiences of elite higher education yet this process did not require or result in a whole sale change, abandonment or 'escape' from valued aspects of their working-class self and family connections. Likewise, we suggest that Hannah did not abandon all performances of femininity and remained intelligible as a young woman (for instance through her appearance, dress and performances of self). However, in line with research conducted with women physicists in higher education (e.g. Ong 2005) who self-consciously 'manage' their femininity, Hannah described engaging 'balancing' aspects of her femininity (for instance, wearing a skirt to school, despite preferring jeans, to counterbalance perceptions of her 'very short' hair). We thus hypothesise that she will continue to have to work hard to regulate and negotiate these balancing acts (so as to maintain intelligibility both in and beyond physics) as she progresses through the physics 'pipeline'. 
Consequently, we suggest that Hannah's self-recognition as being 'good at physics' (and hence her ongoing physics trajectory) remains precarious. Not only does she need to keep performing and re-performing high attainment so as not to be officially debarred at each educational level, but this performance is also required in order for her to retain symbolic/ representational legitimacy as a physicist and, in particular, to mitigate the illegitimacy of her female body within the field of physics. Thus Hannah has the difficult challenge of having to manage the contradiction of her feminine body, working hard to maintain her simultaneous intelligibility as a physicist and as a young woman. While she may continue to use her impressive habitus and resources to navigate a viable position within the field, we would argue that through the maintenance of the notion of the 'effortlessly clever physicist', the field maintains gender inequality and reproduces the dominance of masculinity. Hence we understand both her reservation that her attainment in physics is not effortless and her 'hypervisibility' as a girl in an Advanced level physics class, as exemplifying the ever-shifting ways through which the field maintains a constant dominant masculinised configuration of physics, such that the subject remains aligned 'naturally' with masculinity, despite the presence of female physicists.

Reay and colleagues draw on Puwar's (2004) notion of 'familiar strangers' to describe working class students in elite Higher Education, who are 'fitting in as learners despite their class difference' (Reay et al., 2009, p.1115). We suggest that our data also highlight the ways in which the field of physics cultivates the habitus and hexis of students to ensure that only those 'strangers' who are 'familiar enough' are allowed entry and to remain. That is, how the field of physics cultivates a particular habitus and hexis through female students' 'minds' and bodies which enables the continued reproduction of the elite nature of the field.

\section{Discussion and Conclusions - what is the future for young women in physics?}

In this chapter we employed a feminist Bourdieusian lens to explore what insights it might offer for our understanding of young women's trajectories in, through and out of physics between the ages of 10-19. Our analysis suggests that the field of physics is tightly regulated and strongly orientated to the reproduction of the elite status of the subject. It is arguably a highly efficient and successful field in this respect, given that the eliteness of the field widely recognised and unquestioned and the integral supporting practices and propositions are accepted as doxa. Moreover, like Reay et al. (2009), we found no particular examples of 'painful dislocations' (Baxter and Britton, 2001) and no habitus of recalcitrance (Skeggs, 2004) among our sample of A level physics girls - even among 
those who had been expelled/ debarred. Indeed, we found that the field was remarkably effective in cultivating the bodies and minds of young women physicists to fit the needs and demands of the field - enacting a symbolic violence through which young women blame their own abilities when they are debarred and self-exclude from continuing further. We interpret this as attesting to the power and success of physics in performing its inculcation 'job'.

As Skeggs (2004) discusses, subject choices reveal the dialectic of gender and habitus, such that "The transference of femininity from the student to the school subject and back again to the student exemplifies the dialectic of objectification and embodiment, formed via an 'elective affinity' shaping the habitus' (Skeggs 2004: 22). In our chapter, we explored the complicated dialectics involved when young women negotiate an elite subject that is aligned with masculinity - and the intricate negotiations of embodiment and habitus that are involved.

Our data paint a picture in which physics appears to be a risky and challenging option for young women. Indeed, we argue that Davina, Kate and Mienie's choices not to pursue the subject post-18 can be seen as rational and strategic, given the intractability of gender inequality within the field which render success harder and more precarious due to the unequal 'rules of the game'. As Beck reminds us, risk adheres inversely to the social structure, such that those in positions of power enjoy fewer risks, whereas those who occupy less prestigious positions experience an 'unfortunate abundance' of risk (1992, p.35). Thus physics remains a more risky option for girls than boys and we can see that Davina, Kate and Mienie may have a better chance of 'winning' by pursuing other subjects at university. Indeed, just as elite higher education is a choice that is characterised by 'conscious deliberation and awareness' (Reay et al., 2009: 1110) among working class students, so we suggest that for young women, physics is also both a 'risky' and 'dissonant' choice that needs to be carefully thought through.

The application of our conceptual lens enabled us to identify some key factors and relations which help to explain Hannah's successful trajectory on to a physics degree. Pre-requisites included the continued performance of high attainment, gender alignment with the field, high levels of physicsspecific capital and gender reflexivity. Crucially, Hannah also maintained a self-identification as 'good at physics', despite the dominance of the fantasy of the 'effortlessly clever physicist' which threatens to undermine her legitimacy and ensure and produce the reproduction of the field's elite status. In this respect, we suggest that the field of physics demands that those young women who 
are able to continue with the subject are exceptional and, in Davina's words quoted earlier, 'not like your average person'.

So what hope is there for change and greater gender equity within post-compulsory physics? Our data show how a student's interest, enjoyment, aptitude and passion for the subject are not necessarily sufficient to enable them to pursue it further (Archer et al., 2010). As in the case of Danielle and Davina, even long-held interests and aspirations can be denied and/or 'cultivated away' by the field. Bourdieu argues that pedagogic action - despite entailing symbolic violence -can produce an emancipatory reflexivity:

... the possibility of an emancipation founded on awareness and knowledge of the conditionings undergone and on the imposition of new conditionings designed durably to counter their effects (Bourdieu, 1999c: 340).

While not wishing to dismiss Bourdieu's uncharacteristic optimism, we suggest a more cautious interpretation in the case of women in physics. While we certainly welcome the cultivation of feminist reflexivity among physics students - and recognise that this may be productive on numerous levels - we argue that without addressing the strict regulation of the field and the underlying lack of value accorded to femininity (and other axes of inequality) both within and beyond physics, the social justice potential remains constrained. Indeed, McRobbie (2004) and Fowler (2004) argue that social change comes about not through the resistance of subordinated groups or through reflexive individualization but through shifts in the conditions of social reproduction. As Adkins (2002, 2004) argues, individualization can bring new social divisions into being - explaining how 'reflexivity concerns not a freedom from gender but is actively reworking the social categories of gender' (Adkins, 2004; p.9).

In particular, we suggest that significant change will only be achieved via transformation of the field itself. Such a change would require addressing the technologies and practices - the pedagogic work - which produces the pedagogic action that reproduces the elite status of physics. Hence, we call for the strict gatekeeping practices around attainment to be dismantled and opened up, not least given the key role these practices play in reproducing the doxa of 'hard' (masculine) physics and the notion of the effortlessly clever physicist.

However, we believe that the likelihood of there being any impetus (or not) for such a change will depend on the continued 'success' of the subject. That is, it is likely that change will only be prompted by necessity. Recent policy concerns about the 'crisis' in physics participation (Saltelli \& 
Funtowicz, 2017; Wong, 2016) provide a potential point of leverage here. To date, physics has been arguably highly effective in maintaining its elite status by not letting in the 'wrong' people - who might dilute and/or challenge the subject's elitism - and by ensuring that those who do gain entry are socialised into accepting the status quo. However, arguably these restrictive practices have also led to the subject only 'just' surviving in terms of ensuring a sufficient volume of students entering and continuing with the subject to ensure a sufficient economic rate of return - an issue that is being played out against a backdrop of Higher Education expansion (Smithers, Robinson, \& Gatsby, 2009). Within this neoliberal market logic, (high achieving, middle-class) women have been identified as constituting a potential resource 'pool' of future physicists, which could sustain and sure up the viability of both physics and the wider national knowledge economy (Raelin et al., 2014; The Royal Society, 2008). Yet, the individualised approaches and strategies designed to encourage young women to continue with post-compulsory physics which have typically been pursued to date (being those which are most palatable and in keeping with the logic of the field and the reproduction of the subject's elitism) have failed to produce significant changes in the supply of physics graduates (e.g. Murphy \& Whitelegg, 2006). We thus suggest that it may be an emancipatory reflexivity within the field (rather than just within individual young women's habitus) that is required in order to produce emancipatory potential and to substantially improve gender equity - and young women's possibilities - within the subject. In other words, we suggest that the challenge (and potential) will lie in getting the field of physics (and the myriad of powerful actors within this field) to understand the ways in which social reproduction functions in this space - and to then accept a reduction in their previously-enjoyed privilege in order to genuinely redress the effects of inequality and to open up the field to a more diverse demographic of participants.

\section{References}

Adkins, L. (2002). Reflexivity and the Politics of Qualitative Research. In May, T. (ed.) Qualitative Research: Issues in International Practice: London: Sage.

Adkins, L. (2004). Introduction: Feminism, Bourdieu and after. The Sociological Review, 52, 1-18. doi:10.1111/j.1467-954X.2005.00521.X

Archer, L. \& DeWitt, J. (2016) Understanding Young People's Science Aspirations. London, Routledge

Archer, L., DeWitt, J., Osborne, J., Dillon, J., Willis, B. \& Wong, B. (2010) ““Doing' Science versus 'Being' a Scientist: Examining 10/11-year-old Schoolchildren's Constructions of Science through the Lens of Identity." Science Education 94(4):617-39. 
Archer, L., DeWitt, J., Osborne, J., Dillon, J., Willis, B. \& Wong, B. (2012). Science Aspirations and family habitus: How families shape children's engagement and identification with science. American Education Research Journal, 49(5): 881-908

Archer, L., Dawson E., DeWitt, J., Seakins, A. and Wong, B. (2015). Science capital: a conceptual, methodological, and empirical argument for extending Bourdieusian notions of capital beyond the arts. Journal of Research in Science Teaching 52(7): 922-948

Archer, L., DeWitt, J., Osborne, J., Dillon, J., Willis, B. and Wong. B. (2012). "Balancing acts": Elementary school girls' negotiations of femininity, achievement, and science. Science Education, 96(6): 967-989.

Archer, L., DeWitt, J., Osborne, J., Dillon, J., Willis, B. \& Wong, B. (2013) 'Not girly, not sexy, not glamorous': primary school girls' and parents' constructions of science aspirations. Pedagogy, Culture \& Society, 21(1), 171-194, DOI: 10.1080/14681366.2012.748676

Archer, L., Moote, J., Francis, B., DeWitt, J. \& Yeomans, L. (2017). The 'exceptional' physics/ engineering girl: a sociological analysis of longitudinal data from girls aged 10-16 to explore gendered patterns of post-16 participation. American Educational Research Journal Archer, L., Moote, J., \& MacLeod, E. (under review). "You can't handle the truth!” Pedagogic work and the cultivation of student habitus in the reproduction of Advanced Level Physics as an elite subject. American Educational Research Journal.Baker, D., \& Leary, R. (1995). Letting girls speak out about science. Journal of Research in Science Teaching, 32(1), 3-27.

Baxter, A. \& C. Britton (2001) 'Risk, Identity and Change: Becoming a Mature Student', International Studies in Sociology of Education 11: 87-102.

Beck, U. (1992). Risk Society: Towards a New Modernity. London and New York: Sage.

Blickenstaff, J. C. (2005). Women and science careers: leaky pipeline or gender filter? Gender and Education, 17(4), 369-386.

Bourdieu, P. (1977b). Outline of a Theory of Practice (R. Nice, Trans.) Cambridge, UK: Cambridge University Press.

Bourdieu, P. (1977c). Symbolic Power. In D. Gleeson (Ed.), Identity and structure: issues in the sociology of education (pp. 112-119). Nafferton Driffield, UK: Studies in Education, Ltd.

Bourdieu, P. (1979). Algeria 1960: Essays by Pierre Bourdieu (R. Nice, Trans.). Cambridge, UK:

Cambridge University Press.

Bourdieu, P. (1984). Distinction: a social critique of the judgement of taste. Cambridge, MA:

Harvard University Press.

Bourdieu, P. (1986). The Forms of Capital. In J. G. Richardson (Ed.), Handbook of theory and research for the sociology of education (pp. 241-258). New York, NY: Greenwood Press. 
Bourdieu, P. (1990a). In other words: essays towards a reflexive sociology. Stanford, CA: Stanford University Press.

Bourdieu, P. (1990b). The logic of practice. Cambridge: Polity Press.

Bourdieu, P. (1991). Language and symbolic power (J. B. Thompson Ed.). Cambridge, UK: Polity Press in association with Basil Blackwell.

Bourdieu, P. (1992). Interest, habitus, rationality. In L. J. D. Wacquant \& P. Bourdieu (Eds.), An invitation to reflexive sociology (pp. 115-139). Cambridge, UK: Polity Press.

Bourdieu, P. (1996/2010). The myth of "globalization" and the European welfare state. In G. Sapiro (Ed.), Sociology is a Martial Art: Political Writings by Pierre Bourdieu. New York, NY: New Press.

Bourdieu, P. (1998a). Acts of resistance: against the tyranny of the market. New York, NY: New Press. Bourdieu, P. (1998b). On television and journalism. London: Pluto Press.

Bourdieu, P. (1998c). Practical reason: on the theory of action. Stanford, CA: Stanford University Press.

Bourdieu, P. (1999a). The social conditions of the international circulation of ideas. In R.

Shusterman (Ed.), Bourdieu: a critical reader (pp. 220-229). Malden, MA: Blackwell Publishers.

Bourdieu P. (1999c) 'Scattered Remarks', European Journal of Social Theory 2(3): 334-40.

Bourdieu, P. (1999b). Structures, habitus and practices. In The Polity Reader in Social Theory. Cambridge, UK: Polity.

Bourdieu, P. (1999c). The weight of the world: social suffering in contemporary society. Oxford, UK: Polity.

Bourdieu, P. (1999d) 'The Contradictions of Inheritance', in P. Bourdieu et al. Weight of the

World: Social Suffering in Contemporary Society, pp. 507-13.

Bourdieu, P. (2001). Masculine domination. Stanford, CA: Stanford University Press.

Bourdieu, P. (2005). The Social Structures of the Economy. Cambridge, UK: Polity.

Bourdieu, B., \& Passeron, J. C. (1977). Reproduction in Education. London: Society and Culture

Bourdieu, P., \& Passeron, J. C. (1990). Reproduction: in education, society and culture. (2nd ed.)

London; Beverly Hills, CA: Sage Publications.

Bourdieu, P., Sapiro, G., Ferguson, P. P., Nice, R. W., \& Wacquant, L. J. D. (2010). Sociology is a Martial Art: Political Writings by Pierre Bourdieu: New York, NY: New Press.

Bourdieu, P., \& Wacquant, L. J. D. (1992). An invitation to reflexive sociology. Cambridge, UK: Polity Press. 
Calabrese Barton, A. \& Brickhouse, N.W. (2006). Engaging girls in science. In C. Skelton, B. Francis, \& L. Smulyan (Eds.), The Sage handbook of gender and education (pp. 221-35). Thousand Oaks, CA: Sage.

Calabrese Barton, A., Tan, E., \& Rivet, A. (2008). Creating hybrid spaces for engaging school science among urban middle school girls. American Educational Research Journal, 45(1), 68-103. Caleon, I. S., \& Subramaniam, R. (2008). Attitudes towards science of intellectually gifted and mainstream upper primary students in Singapore. Journal of Research in Science Teaching, 45(8), 940-954.

Carlone, H. B. (2003). (Re)producing good science students: Girls' participation in high school physics. Journal of Women and Minorities in Science and Engineering, 9(1), 17-34.

Carlone, H.B. (2004). The cultural production of science in reform-based physics: Girls' access, participation, and resistance. Journal of Research in Science Teaching, 41, 392-414.

Ceci, S. J., Williams, W. M., \& Barnett, S. M. (2009). Women's underrepresentation in science: Sociocultural and biological considerations. Psychological Bulletin, 135(2), 218-261.

Danielsson, A. T. (2012). Exploring woman university physics students "doing gender" and "doing physics". Gender and Education, 24(1), 25-39.

Darke, K., Clewell, B. \& Sevo, R. (2002). Meeting the challenge: The impact of the National Science Foundation's Program for Women and Girls. Journal of Women and Minorities in Science and Engineering, 8, 285-303.

DeWitt, J. \& Archer, L. (2015). Who aspires to a science career? A comparison of survey responses from primary and secondary school students. International Journal of Science Education, 37(13): 2170-2192

Dewitt, J. E., Archer, L. \& Osborne, J. F. (2014). Science-related aspirations across the primarysecondary divide: evidence from two surveys in England. International Journal of Science Education, 36(10):1609-1629

Dewitt, J. E., Archer, L. \& Osborne, J. F. (2013). Nerdy, brainy and normal: children's and parents' constructions of those who are highly engaged with science. Research in Science Education, 43(4): $1455-1476$

DeWitt, J., Archer, L., Osborne, J., Dillon, J., Willis, B. \& Wong, B. (2011). High aspirations but low progression: the science aspirations-careers paradox amongst minority ethnic students. International Journal of Science and Mathematics Education, 9(2): 243-271 DeWitt, J. E., Archer, L. et al (2013). Young children's aspiration in Science: The unequivocal, the uncertain and the unthinkable. International Journal of Science Education, 35(6): 1037-1063. 
Fadigan, K., \& Hammrich, P. (2004). A longitudinal study of the educational and career trajectories of female participants of an urban informal science education program. Journal of Research in Science Teaching, 41(8), 835-860.

Farenga, S.J. \& Joyce, B.A. (1999). Intentions of young students to enroll in science courses in the future: An examination of gender differences. Science Education, 83, 55-75.

Faulkner, Wendy. (2007). 'Nuts and Bolts and People': Gender-Troubled Engineering Identities. Social Studies of Science, 37(3), 331-356.

Fennema, E. \& Peterson, P.L. (1985). Autonomous learning behavior: A possible explanation of sex-related differences in mathematics. Educational Studies in Mathematics, 16, 309-11.

Francis, B. (2000). The gendered subject: Students' subject preferences and discussions of gender and subject ability. Oxford Review of Education, 26, 35-48.

Francis, B., Archer, L., Moote, J., DeWitt, J., \& Yeomans, L. (2017). Femininity, science, and the denigration of the girly girl, British Journal of Sociology of Education, 38(8), 1097-1110, DOI: 10.1080/01425692.2016.1253455

Francis, B. \& Skelton, C. (2005) Reassessing Gender and Achievement. London: Routledge. Smithers, A., Robinson, P., \& Gatsby (2009). Physics participation and policies: Lessons from abroad. Carmichael Press, London.

Gonsalves, A. (2014). "Physics and the girly girl - there is a contradiction somewhere": Doctoral students' positioning around discourses of gender and competence in physics. Special issue on Gender and Science in Cultural Studies in Science Education, 9, 503-521.

Harding, S. (1998). Women, science, and society. Science, 281(5383), 1599-600.

Haworth, C.M.A., Dale, P. \& Plomin, R. (2008). A twin study into the genetic and environmental influences on academic performance in science in nine-year-old boys and girls. International Journal of Science Education, 30, 1003-25.

Haussler, P., \& Hoffmann, L. (2002). An intervention study to enhance girls' interest, self-concept, and achievement in physics class. Journal of Research in Science Teaching, 39(9), 870-888.

Jenkins, R. (2006). Pierre Bourdieu: Revised Edition. London: Routledge.

Lawler, S. (2004). Rules of engagement: Habitus, power and resistance. The Sociological Review, 52: 110-128. doi:10.1111/j.1467-954X.2005.00527.x

McNay, L. (1999). Gender, Habitus and the Field: Pierre Bourdieu and the Limits of Reflexivity.

Theory, Culture \& Society 16(1): 95-117. doi:10.1177/026327699016001007.

McRobbie, A. (2004). Post-Feminism and Popular Culture. Feminist Media Studies, 4(3), 255-264.

Moi, T. (1991) ‘Appropriating Bourdieu: Feminist Theory and Pierre Bourdieu’s Sociology

ofCulture'. New Literary History 22(4): 1017-1049. 
Moi, T. (1999) What Is A Woman? Oxford: Oxford University Press.

Mujtaba, T. \& Reiss, M. J. (2013), What sort of girl wants to study physics after the age of 16 ?

Findings from a large-scale UK survey. International Journal of Science Education, 35(17), 29792998. Doi: 10.1080/09500693.2012.681076.

Murphy, C. \& Beggs, J. (2003) Children's perceptions of school science. School Science Review, 84(308), 109-116.

Murphy, P., \& Whitelegg, E. (2006). Girls in the physics classroom: A review of the research on the participation of girls in physics. London: Institute of Physics.

Ong, M. (2005). Body projects of young women of color in physics: Intersections of gender, race, and science. Social Problems, 52, 593-617.

Puwar, N. (2004) Space Invaders: Race, Gender and Bodies out of Place. Oxford:

Berg.

Reay, D., Crozier, G., \& Clayton, J. (2009). 'Strangers in Paradise’? Working-class Students in Elite Universities. Sociology, 43(6), 1103-1121. doi: 10.1177/0038038509345700.

Raelin, J.A., Bailey, M.B., Hamann, J., Pendleton, L.K., Reisberg, R. \& Whitman, D.L. (2014). The gendered effect of cooperative education, contextual support, and self-efficacy on undergraduate retention. Journal of Engineering Education, 103 (4), 599-624.

Saltelli, A, \& Funtowics, S. (2017). What is science's crisis really about. Futures, 91, 5-11.

Skeggs, B. (2004) 'Exchange, Value and Affect: Bourdieu and "the Self”, in L. Adkins

and B. Skeggs Feminism after Bourdieu, pp. 75-89. Oxford: Blackwell.

Smith, E. (2010). Do we need more scientists? A long-term view of patterns of participation in UK undergraduate science programmes. Cambridge Journal of Education, 40, 281-98.

Smith, E. (2010). Is there a crisis in school science education in the UK? Educational Review, 62(2), 189-202.

Smith, E. (2011). Women into science and engineering? Gendered participation in higher education STEM subjects. British Educational Research Journal, 37, 993-1014.

The Royal Society. (2008). A higher decree of concern. Policy Document. February, 2008.

Thomson, D. (2015). Is A-level physics too hard (and media studies too easy)? Education Data Lab. Published online on 20th October 2015. Accessed 06/06/2018 at < https://ffteducationdatalab.org.uk/2015/10/is-a-level-physics-too-hard-and-media-studies-tooeasy/>

Thomson, D. (2016) Which are the most difficult subjects at GCSE? Education Data Lab. Published online Feb $23^{\text {rd }} 2016$. Accessed 27/6/16. 
Tracy, C. (2016a). The problem of inter-subject comparability. Institute of Physics. Published online on 17 February 2016. Accessed 06/06/2018 at < http://www.iopblog.org/the-problem-ofinter-subject-comparability/>

Tracy, C. (2016b). Do students choose subjects based on how hard they are graded? Institute of Physics. Published online on 19 April 2016. Accessed 06/06/2018 at < http://www.iopblog.org/theeffects-of-grading-on-choice/>

Tytler, R., J. Osborne, G. Williams, K. Tytler, and J. Cripps Clark. (2008). Opening up pathways: Engagement in STEM across the Primary-Secondary school transition. Australian Department of Education, Employment and Workplace Relations, Canberra, A.C.T.

Wong B. (2016) The 'Crisis' in Science Participation. In: Science Education, Career Aspirations and Minority Ethnic Students. Palgrave Macmillan, London

\section{Drop/ move?}

"Yet here the normalcy of gendered reproduction works very differently for boys and girls. For girls it can offer a limited form of capital if they conform to gender normalcy. For boys it offers masculine power, institutionalised in the school as a form of symbolic capital that (as with the family) represents accumulated privilege in other fields. Yet the failure to draw attention to how normalcy works differently through gender as a form of capital leads t o significant problems' (for B's theory) (Skeggs, 2004: 22).

“embodied action concerns sedimented or accumulated - but usually forgotten - history", embodiment is "an enactment of the past" (Adkins, 2004: 14).

\footnotetext{
'Advanced Level / A level examinations are the 'gold standard' post-compulsory academic qualifications that are studied over two years with final examinations taken at age 18. A levels are the most usual qualifications that provide entry to university degree courses.
} 